CATALLAXY

Volume 4 Issue 2 December 2019

e-ISSN 2544-090X

¿ www.catallaxy.pl

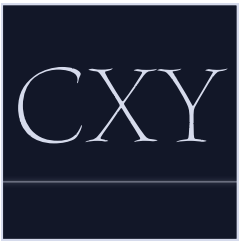

Oryginalny artykut przeglądowy

otrzymano: 27.05.2019 / zaakceptowano: 13.09.2019 / opublikowano online: 17.09.2019

Kowalski, D. (2019). Neoliberalizm szkoły chicagowskiej a kryzys gospodarczy XXI wieku w Stanach Zjednoczonych. Catallaxy, 4(2): 95-101. doi:10.24136/cxy.2019.009.

\title{
Neoliberalizm szkoły chicagowskiej a kryzys gospodarczy XXI wieku w Stanach Zjednoczonych
}

\author{
DAMIAN KOWALSKI \\ Uniwersytet Mikołaja Kopernika w Toruniu, Wydział Nauk Ekonomicznych i Zarzadzania, ul. Gagarina 13a, \\ 87-100 Toruń, Polska \\ వdamian.kowalski955@gmail.com \\ (iD) orcid.org/0000-0002-0653-1967
}

\begin{abstract}
Abstrakt
Motywacja: Krach na amerykańskim rynku finansowym w 2008 roku zapoczątkował kryzys o charakterze globalnym. Rozpoczęła się poważna debata nad jego przyczynami, a w niej pojawiają się głosy o istotnej roli neoliberalnych założeń nurtu chicagowskiego, postrzeganego jako koncepcja ekonomiczna i ideologia dotykająca szeroko rozumianej sfery polityczno-społecznej. Chęć przedstawienia takiej krytycznej oceny stanowiła bezpośrednią przyczynę podjęcia niniejszego tematu.

Cel: Celem artykułu jest zidentyfikowanie potencjalnego wpływu neoliberalizmu szkoły chicagowskiej oraz polityki gospodarczej państwa, prowadzonej na gruncie tej doktryny na kryzys gospodarczy 2008+ w Stanach Zjednoczonych. Materiały i metody: Wykorzystano metodę krytycznej analizy literatury z zakresu teorii kryzysów gospodarczych, neoliberalizmu, neoliberalizmu szkoły chicagowskiej oraz kryzysu XXI wieku.

Wyniki: Ze względu na rozbieżności, trudno jednoznacznie wskazać, czy i w jakim stopniu neoliberalizm nurtu chicagowskiego i polityka gospodarcza państwa, prowadzona na gruncie tej doktryny przyczynily się do kryzysu gospodarczego 2008+. Ze względu na wyraźnie przeważające głosy przeciwników tej doktryny i ich refleksje, można stwierdzić istnienie takiego wplywu.
\end{abstract}

Stowa kluczowe: kryzys; Stany Zjednoczone; neoliberalizm nurtu chicagowskiego

JEL: G2; N2; E5

\section{Wprowadzenie}

Osoby podejmujące głos $\mathrm{w}$ dyskusji na temat przyczyn kryzysu gospodarczego XXI w Stanach Zjednoczonych, jako bezpośrednią przyczynę wskazują pęknięcie bańki spekulacyjnej na rynku nieruchomości. Zidentyfikowano ją w sierpniu 2002 roku, zaś 2005 rok uważa się za jej szczyt. Wartość sprzedanych nieruchomości była wówczas pięciokrotnie wyższa niż w 1990 roku (wzrost cen o ponad 170\% w latach 1990-2005). W 2008 roku oceniono, że 700 mld USD zostało przeznaczone przez amerykańskie instytucje finansowe na kredyty typu subprime, udzielane podmiotom, które nie wykazywały zdolności kredytowej. Błędnie zakładano, że nieruchomości to bardzo bezpieczna inwestycja (Szymański, 2009, ss. 40-41). W debacie tej pojawiło się wiele głosów o istotnej roli neoliberalizmu nurtu chicagowskiego i polityki gospodarczej pań- 
stwa, prowadzonej na gruncie tej doktryny. Postrzega się ją nie tylko jako koncepcję ekonomiczną, ideę związaną z gospodarką, ale téz jako ideologię związaną z szeroko rozumianą sferą polityczno-społeczną.

Założenia neoliberalizmu, niezależnie od ewolucji idei, można podsumować jako tzw. „świętą triadę”: prywatyzacja, deregulacja, makroekonomiczna stabilizacja. Obecnie można dołączyć do tego globalizację (Pysz, 2014, s. 18).

Analizując potencjalny wpływ neoliberalizmu szkoły chicagowskiej oraz polityki gospodarczej państwa, prowadzonej na gruncie tej doktryny na kryzys gospodarczy 2008+, uwzględniono głosy krytyków i zwolennikom neoliberalizmu.

W sekcji 2. dokonano przeglądu literatury przedmiotu. W sekcji 3. opisano wykorzystane materiały i metody. W sekcji 4. przedstawiono otrzymane wyniki, natomiast $\mathrm{w}$ sekcji 5. zawarto podsumowanie przeprowadzonej analizy.

\section{Przegląd literatury}

Kryzys w Stanach Zjednoczonych i kryzys globalny 2008+ jest tematem bardzo wielu specjalistycznych publikacji z zakresu teorii kryzysów gospodarczych, neoliberalizmu, neoliberalizmu szkoły chicagowskiej oraz kryzysu w XXI wieku. Do autorów zagranicznych poruszających tę tematykę należą m.in.: J.E. Stiglitz, N. Roubini, P. Krugman, R.G. Rajan, J. Price, K. Polanyi, B. Bernanke. Wśród polskich można wymienić m.in.: E. Mączyńską, D.A. Michałowską, W. Szymańskiego, L. Balcerowicza, E. Potulicką, S. Ładykę, M. Walkowskiego, W. Nawrot, R. Wosia, J. Kloczkowskiego, A. Szahaja, J. Mizińską, B. Fiedora oraz T. Markiewkę.

\section{Materiały i metody}

Do realizacji celu wykorzystano metodę krytycznej analizy literatury $z$ zakresu teorii kryzysów gospodarczych, neoliberalizmu, neoliberalizmu szkoły chicagowskiej, kry- zysu XXI wieku. Literaturę dobrano tak, aby uwzględnić stanowisko zarówno zwolenników, jak i przeciwników neoliberalizmu szkoły chicagowskiej.

\section{Wyniki badania}

\subsection{Krytyka neoliberalizmu}

N. Roubini i S. Mihm (2011, ss. 21-44), jako jedni z nielicznych, przestrzegali przed kryzysem: „ludzie wierzyli w rzeczy, w które wierzyć nie powinni, ufali ludziom, którym ufać nie powinni. Na rynku nie było dyscypliny, $\mathrm{w}$ zarządzaniu firmami popełniano błędy, $w$ ramach instytucji finansowych istniały potężne konflikty interesów, a Stanowa Komisja Papierów Wartościowych (United States Securities and Exchange) nie wykonywała swoich obowiązków".

Krytyk neoliberalnej strategii rozwoju, P. Krugman, pisal, że zwyczaj kupowania za pożyczone pieniądze był zawsze normą dla Amerykanów. Tym razem, znacznie obniżono standardy. W jakimś stopniu był to wynik irracjonalnego entuzjazmu wśród amerykańskich rodzin, bez refleksji nad konsekwencjami. W momencie, gdy doszło do poważnych problemów ze spłatą kredytów, w typowym dla neoliberalizmu stylu, ze strony banków nie dochodziło do propozycji ugody $z$ właścicielami nieruchomości $w$ celu zmniejszenia rat kredytów hipotecznych. Poza tym, kredyty subprime $z$ reguły nie były udzielane przez banki, które je później obsługiwały, lecz przez pośredników szybko sprzedających zobowiązania instytucjom finansowym. Przeszkody prawne powstawały przez złożoność inżynierii finansowej wspierającej kredyty subprime (Roubini i Mihm, 2011, ss. 150-151).

Niektórzy uważają, że nie byłoby największego boomu na rynku nieruchomości, gdyby nie działania A. Greenspana, przewodniczącego Rady Gubernatorów Systemu Rezerwy Federalnej (Federal Reserve System, FED) w latach 1987-2006. Po zamachach na Światowe Centrum Handlu (World Trade Center, WTC) w 2001 roku, doszło do obniżki poziomu stóp 
procentowych FED, co zredukowało koszt kredytu. Amerykanie, zachęceni wizją społeczeństwa własności, zaczęli masowo zaciągać kredyty hipoteczne na zakup nieruchomości. Następnie, pod zastaw tych nieruchomości udzielano kolejnych kredytów, np. na cele konsumpcyjne. Uważa się, że bańka powinna pęknąć latem 2005 roku, gdy w Stanach Zjednoczonych nie było już wiarygodnych kredytobiorców, lecz chcąc przedłużyć dobrą passę, kredyty były udzielane niewypłacalnym podmiotom. W celu zabezpieczenia, przekształcano ryzykowne kredyty w tzw. skolateralizowane obligacje dłużne (collateralized debt obligation, CDO). Niewielu rozumiało ich konstrukcje, lecz specjaliści z Wall Street uspokajali, a sektor finansów opanowało szaleństwo tłumów (Walkowski, 2013, s. 183.).

Wskazuje się, że kolejnym potencjalnym problemem mogła być celowa dezinformacja społeczna. B. Bernanke, przewodniczący Rady Gubernatorów FED w latach 2006-2014, informował Kongres: „wszystko wskazuje na to, że w ostatnim czasie udało nam się zdecydowanie ograniczyć wpływ, jaki na resztę gospodarki i rynki finansowe wywierały problemy związane z kredytami złej jakości”. D.L. Luskin, giełdowy autorytet i komentator branży finansowej, po upadku Federalnego Narodowego Stowarzyszenia Kredytów Hipotecznych (Federal National Mortgage Association, Fannie Mae) oraz Federalnej Korporacji Kredytów na Budowę Domów (Federal Home Loan Mortgage Corporation, Freddie Mac) oznajmił: „w najbliższym czasie Stany Zjednoczone czeka ożywienie gospodarcze" (Roubini i Mihm, 2011, ss. 117-132).

J.E. Stiglitz (2012, ss. 205-215) wskazał kilka błędów:

- powołanie A. Greenspana na stanowisko przewodniczącego FED, który nie widział konieczności regulowania rynków finansowych, a za jego kadencji pękły dwie bańki spekulacyjne;

- zniesienie przez Kongres w listopadzie 1999 roku ustawy Glass-Steagall Act, zgodnie z którą dokonano rozdziału banków komercyjnych udzielających kredytów od banków inwestycyjnych przygotowu- jących sprzedaż akcji i obligacji, co gwarantowało, że banki nie będą nadmiernie ryzykować;

- wprowadzenie ulg podatkowych dla korporacji i zamożnych obywateli za prezydentury G.W. Busha w 2001 i w 2003 roku; - obniżenie stóp procentowych przez FED;

- redukowanie stawek opodatkowania zysków kapitałowych, co gwarantowało niższe podatki, płacone przez spekulantów giełdowych;

- istnienie szkodliwych zasad funkcjonowania agencji ratingowych finansowanych przez oceniane podmioty;

- przyjęcie pakietu ratunkowego (tzw. pakietu Paulsona) dotującego tylko wybrane podmioty (np. AIG, Freddie Mac, Bear Stearns, Fannie Mae), co potęgowało chaos.

W. Szymański (2009, ss. 41-48) zauważa, że globalizacja i związane $z$ nią uwolnienie rynków kapitałowych spowodowała niestabilność ekonomiczną. Jej następstwami są: ograniczenie władzy gospodarczej państw, osłabienie demokracji i kontroli społecznej nad procesami gospodarczymi oraz zdominowanie gospodarki przez interesy jednostkowe i partykularne, które nie poddają się procedurom kompromisowym. Wzrósł zakres odłączenia procesów inwestowania od tworzenia kapitału oraz sfery finansowej gospodarki od sfery realnej. Powszechnie tolerowano zadłużenie państw, przedsiębiorstw czy poszczególnych ludzi. Kreowano optymizm, zaufanie do mechanizmów rynkowych oraz instytucji finansowych, a także przekonanie, że elitom finansowym można ufać. Państwo zaczęło tracić suwerenność w tych sferach, w których dochodziło do konfliktu $z$ kapitałem.

J.E. Stiglitz (2010, ss. 15-16) stwierdzit: „współczesna ekonomia, z jej wiarą w wolne rynki i globalizację, obiecywała prosperity dla wszystkich. (...) Wielka Recesja (...) zdruzgotała te iluzje i zmusza nas do przemyślenia pewnych, długo hołubionych poglądów".

J.E. Stiglitz (2010, s. 16) przyznaje, że rynki są istotą sukcesu gospodarki, ale podważa te doktryny wolnorynkowe, które wiodły prym przez ćwierć stulecia, czyli neoli- 
beralizm w wersji chicagowskiej. Według tych koncepcji:

- efektywne są jedynie rynki wolne i niczym nieskrępowane, a w przypadku błędów, rynki same je skorygują;

- najlepszy rząd to mały rząd;

- regulacja nie stymuluje innowacyjności;

- banki centralne powinny być niezależne, a ich celem ma być utrzymanie niskiej inflacji.

„Wielka Recesja 2008 roku jest nieuchronną konsekwencją polityki wdrażanej w poprzedzających ją latach (...) została ukształtowana przez uprzywilejowane interesy - interesy rynków finansowych".

G. Kołodko twierdzil, że ostatni kryzys był kryzysem systemu, a nie kolejnym przypadkiem, który można odnieść do cyklu koniunkturalnego. Był to szczególnie kryzys neoliberalnej mutacji kapitalizmu. Nie mógłby on wystąpić w państwach społecznej gospodarki wolnorynkowej, np. w Norwegii (Ładyka, 2012, ss. 21-22).

A. Szahaj $(2014$, s. 191) podważa ogromną wiarę neoliberałów w nieskrępowane mechanizmy wolnorynkowe, $w$ ich wszechmoc czy zgodę z ludzką naturą: „nie ma dnia, abym nie usłyszal (...), nie przeczytał (...), że tego i tego nie należy robić, bo źle zareagują rynki finansowe (...) brak informacji na temat tego, co kryje się za owymi magicznymi słowami rynki finansowe, jest nader charakterystyczny. Jest bowiem elementem strategii mającej na celu przekonanie, że istnieją jakiej obiektywne siły pozostające poza kontrolą kogokolwiek (...)".

Warte uwagi wydają się przemyślenia J. Mizińskiej (2016, ss. 7-8), która twierdzi, że neoliberalny konsumpcjonizm, „sukcesizm”, preferowanie egocentryzmu, brak wrażliwości na drugiego człowieka, bezwzględność, cynizm, spryt czy bezwstyd wydają się w neoliberalnym systemie niezbędne dla osiągnięcia komfortu materialnego czy psychicznego. Preferowany homo oeconomicus, obywatel „konsumpcyjnego raju”, jest, zdaniem J. Mizińskiej, „radykalną negacją dotychczasowych koncepcji człowieka i jego świata".

\subsection{Zwolennicy neoliberalizmu}

L. Balcerowicz (2010, ss. 5-15) przyznał, że na początku w Stanach Zjednoczonych, a później $\mathrm{w}$ wielu państwach rozwiniętych, doszło w sektorze finansowym do poważnych zaburzeń. Jego zdaniem, głębsze ich źródła nie tkwią, choć mogą, w tym sektorze, ale $w$ warunkach jego działania: otoczeniu silnie kształtowanym przez rządy, parlamenty i banki centralne, a także przez politykę pieniężną, nadzorczą, fiskalną oraz regulacyjną.

J.B. Taylor (2010) winą za kryzys obarczał rząd amerykański, w tym departamentu skarbu, działania FED oraz gigantów rynku hipotecznego, czyli Freddie Mac i Fannie Mae, których, jego zdaniem, nie można uznać za instytucje prywatne, ale za quasi-rządowe. Uważa, że dużym błędem była polityka monetarna będąca polityką nadmiernie niskich stóp procentowych. J.B. Taylor nie widzi w ogóle winy po stronie prywatnych banków, instytucji finansowych czy ogólnie prywatnego biznesu (Lubowski, 2010).

L. Balcerowicz (2012, ss. 25, 53-54) uważa, że nie ma alternatywy dla neoliberalizmu, który uznaje prawo własności i wolny rynek, a te są konsekwencją naturalnego prawa człowieka. Poza tym uważa, że naturalne zasady są łamane $w$ tych państwach, gdzie dopuszcza się interwencjonizm państwowy generujący kryzysy i nierozwiązujący żadnych poważnych problemów. Zdaniem L. Balcerowicza, wystarczy uwolnić bezosobowe mechanizmy wolnorynkowe, zaprzestać ich krępowania, a w naturalny sposób rozprzestrzenią się po świecie i korzystnie wpłyną na gospodarkę.

Profesor ekonomii, P. Booth, uważa, że błędem jest obarczanie winą za kryzys bankierów niepodlegających nadzorowi oraz kontroli, „kierujących się rzekomo chciwością, żądzą zysku i pogonią za premiami”. Twier$\mathrm{dzi}$ on, że zagrożenie stanowił pewien trend myślenia o rynkach finansowych, wspierany i rozpowszechniany przez rząd amerykański czy szerzej regulatorów rynku. Nazywany jest on "skrzywieniem na korzyść ubogich". Wynikał on z przekonania, $\mathrm{m}$,in. ówczesnego 
prezydenta B. Clintona, że biedniejsza część społeczeństwa może się „włączyć w główny nurt życia," jeśli będzie miała godne miejsce do zamieszkania (O'Sullivan, 2010, ss. 14-29).

Neoliberalnie nastawieni badacze i komentatorzy twierdzą, że poważnym błędem było uchwalenie w Stanach Zjednoczonych aktów prawnych, które umożliwiały, czy zachęcały, do udzielania kredytów tym grupom społecznym, które miały bardzo niskie dochody. Za złe uważają powołanie i dotowanie służących temu instytucji, czyli m.in. Fannie Mae i Freddie Mac (Górczyńska i Szczepaniak, 2009, ss. 55-65; Kunowska, 2009, ss. 69-74).

Zdaniem D. Tuska, rozpowszechnianie oraz wzmacnianie nieskrępowanych mechanizmów wolnorynkowych zapobiega „politycznemu rozkładowi", a także chroni przed biedą, głodem czy totalnym konfliktem. Jego poglądy bliskie są opiniom M. Friedmana, który uważa, że wolny rynek jest doskonałym zamiennikiem polityki, rozumianej szeroko, jak i w odniesieniu do usankcjonowanej instytucjonalnie władzy. Według D. Tuska, nieskrępowany, wolny rynek pomaga $\mathrm{w}$ redukcji problemów, a potęguje je protekcjonizm. Receptą na rozwiązywanie sytuacji kryzysowych i zagadnień politycznych, jest osłabienie wpływu rządów na gospodarkę i stworzenie, dzięki temu, szerokiej przestrzeni dla nieskrępowanego działania mechanizmów rynkowych (Markiewka, 2017, ss. 234-235).

W. Gadomski, publicysta ekonomiczny Gazety Wyborczej uważa, że procesy wolnorynkowe są naturalne, dzieją się spontanicznie oraz niezależnie od decyzji politycznych. Politycy popełniają błąd, gdy ingerują $\mathrm{w}$ te mechanizmy. W. Gadomski dopuszcza jednak interwencję państwa, ale tylko w pewnym zakresie: mniej programów socjalnych, likwidacja przywilejów branżowych, bardziej elastyczne reguły rynku pracy (Markiewka, 2017, ss. 225-226).

\section{Zakończenie}

Od momentu pojawienia się kryzysu w Stanach Zjednoczonych, w licznych publikacjach naukowych i prasowych formułowano różne tezy dotyczące jego przyczyn. Nietrudno podzielić te wypowiedzi na głos krytyków i zwolenników neoliberalizmu.

Dokonując przeglądu literatury $\mathrm{w}$ tym zakresie, nie tylko przywołanej w niniejszym artykule, bardzo łatwo znaleźć dużą liczbę pozycji wskazujących na neoliberalizm wersji chicagowskiej jako główne, bądź istotne, źródło kryzysu czy jako ideologię, która w świetle kryzysu wyraźnie się nie sprawdziła. Trudniej o publikacje traktujące o kryzysie z pominięciem jakiejkolwiek podbudowy ideologicznej. Do nielicznych pozycji można zaliczyć te, których autorami są zwolennicy neoliberalizmu, mimo powszechnej obecności tej doktryny, nie tylko w sferze ekonomiczno-gospodarczej.

Krytycy współczesnej neoliberalnej wersji kapitalizmu zazwyczaj podkreślają spektakularny wzrost roli oraz znaczenia kapitału spekulacyjnego, a także błędy, które wiązały się $z$ polityką deregulacji rynków finansowych. Wśród tych krytyków, można znaleźć opinie o niepohamowanej żądzy zysku, chciwości czy nieprzestrzeganiu zasad etyki zawodowej przez bankierów oraz przedstawicieli instytucji współpracujących $z$ nimi, np. przez agencje ratingowe, na czele $z$ tzw. wielką trójką (Moody's, Fitch, Standard E Poor's). Pojawiają się opinie o zbyt dużym wpływie przedstawicieli Wall Street na politykę rządu amerykańskiego.

Podsumowując rozważania o kryzysie, można uznać, że ludzi o różnym poziomie zamożności opanowała jakaś przemożna chęć posiadania, zgodnie $z$ zasadami:. „mieć ponad wszystko" $i$,zysk ponad wszystko".

Zwolennicy neoliberalnej globalizacji ekonomicznej oraz finansowej uważają, że odpowiedzialność ponoszą nie rynki finansowe, ale rząd amerykański ze względu na swoje nieracjonalne działania. Szczególnie negatywnie oceniają błędną politykę monetarną prowadzoną przez FED.

$\mathrm{Ci}$, którzy wierzyli i wierzą w samoregulacyjną sprawność rynku, jako przyczynę kryzysu podają politykę nadmiernej interwencji i regulacji czy błędną politykę gospodarczą państw. Natomiast ci, którzy nie popierają deregulacji, jako powód podają neoliberalne doktrynerstwo, a także politykę ogranicza- 
nia odpowiednich regulacji, czyli kontroli i nadzoru organów państwa nad rynkiem finansowym. Zauważa się jednak, że lista czynników, które spowodowały kryzys jest znacznie dłuższa.

Wydaje się, że ocena wpływu neoliberalizmu nurtu chicagowskiego na kryzys finansowy wynika nie tylko $z$ wiedzy i obiektywnego spojrzenia na zjawiska ekonomiczne i gospodarcze, ale też, a może przede wszystkim, ze światopoglądu wykraczającego poza sferę ekonomii i gospodarki.

Nie wszystkich, którzy się wypowiadają, można jednoznacznie zaliczyć do krytyków czy też zwolenników neoliberalizmu nurtu chicagowskiego. Przykładem jest B. Fiedor (2010, s. 461), który uważa, że nie można na kryzys i rolę państwa patrzeć jedynie z perspektywy neoliberalnej, bliskiej keynesizmowi czy choćby teorii realnego cyklu koniunkturalnego. Zasadne, według B. Fiedora, jest „podejście eklektyczne” zarówno w kontekście przyczyn kryzysu, jak i poszukiwania mechanizmów oraz instrumentów niwelowania i zapobiegania kryzysom, a także pro wzrostowej polityki państwa. B. Fiedor zaleca, aby opierać się „na dorobku wielu, niekiedy konkurujących między sobą, teorii i modeli".

Dokonana analiza oraz własne przemyślenia pozwalają odnieść się do celu niniejszego artykułu i stwierdzić, że neoliberalizm nurtu chicagowskiego oraz polityka gospodarcza państwa, prowadzona na gruncie tej doktryny, przyczynity się do kryzysu gospodarczego 2008+ w Stanach Zjednoczonych, a głównym powodem była deregulacja. Wydaje się, że opinie krytyków neoliberalizmu są racjonalnie umotywowane, zaś zwolenników mało przekonywujące, chociażby ze względu na bezkrytyczny kult samoregulującego się wolnego rynku jako czegoś naturalnego i rodzącego się w sposób spontaniczny, a także ze względu na radykalny sprzeciw wobec ingerencji państwowych.

\section{Bibliografia}

Balcerowicz, L. (2010). Przedmowa. W: J.B. Taylor. Zrozumieć kryzys finansowy: przyczyny, skutki, interpretacje. Warszawa: PWN.

Balcerowicz, L. (2012). Odkrywając wolność: przeciw zniewoleniu umystów. Poznań: Zysk i S-ka.

Fiedor, B. (2010). Kryzys gospodarczy a kryzys ekonomii jako nauki. Ekonomista, 4.

Górczyńska, A., i Szczepaniak, K. (2009). Formuła partnerstwa publiczno-prywatnego $\mathrm{w}$ warunkach kryzysowych. W: S. Antkiewicz, i M. Pronobis M., (red.), Gospodarka w warunkach kryzysu. Warszawa: CeDeWu.

Kowalski, D. (2018). Neoliberalizm nurtu chicagowskiego a kryzys gospodarczy 2008+ w Stanach Zjednoczonych: ujęcie krytyczne. Uniwersytet Mikołaja Kopernika, Torun.

Kunowska, K. (2009). Rola, w dobie kryzysu, wydawanych przez samorządowe organy podatkowe indywidualnych interpretacji przepisów prawa podatkowego. W: S. Antkiewicz, i M. Pronobis M., (red.), Gospodarka w warunkach kryzysu. Warszawa: CeDeWu.

Lubowski, A. (2010). Przyczyny kryzysu: wywiad $z$ prof. Johnem B. Taylorem. Pobrane 12.09.2019 $z$ https://www.polityka.pl.

Ładyka, S. (2012). Liberalizm czy neoliberalizm w polityce gospodarczej państwa. Prace i $\mathrm{Ma}$ teriaty Instytutu Handlu Zagranicznego Uniwersytetu Gdańskiego, 31(2). doi:10.4467/2353949 6IB.12.001.2626.

Markiewka, T. (2017). Język neoliberalizmu: filozofia, polityka i media. Toruń: UMK.

Mizińska, J. (2016). Patologia znormalizowana: narcyz, midas i singiel. Kultura $i$ Wartości, 18. doi:10.17951/kw.2016.18.7.

O'Sullivan, J. (2010). Finansowa burza. W: J. Kloczkowski, i J. Price (red.), Platon na Wall Street: konserwatywne refleksje o kryzysie ekonomicznym. Kraków: Ośrodek Myśli Politycznej.

Pysz, P. (2014). Teoretyczne podstawy badań ładu gospodarczego stanowionego i spontanicznego w transformacji systemowej byłej NRD i Polski 1990-2010. W: A. Grabska, M. Moszyński, i P. Pysz (red.), Stanowiony i spontaniczny lad gospodarczy $w$ procesie transformacji systemowej Polski $i$ bytej NRD. Toruń: Instytut Badań Gospodarczych.

Roubini, N. i Mihm, S. (2011). Ekonomia kryzysu. Warszawa: Wolters Kluwer Business.

Stiglitz, J.E. (2010). Freefall: jazda bez trzymanki: Ameryka, wolne rynki i tonięcie gospodarki światowej. Warszawa: PTE. 
Stiglitz, J.E. (2012). Kapitalistyczne głupstwa: pięć najpoważniejszych błędów, które doprowadziły do krachu. W: G. Carter (red.), Na krawędzi: opowieści o kryzysie: prawdziwe historie $z$ Wall Street $z$ magazynu Vanity Fair. Warszawa: Kurhaus.

Szahaj, A. (2014). Kapitalizm drobnego druku. Warszawa: Instytut Wydawniczy Książka i Prasa.

Szymański, W. (2009). Kryzys globalny: pierwsze przybliżenie. Warszawa: Difin.

Taylor, J.B. (2010). Zrozumieć kryzys finansowy: przyczyny, skutki, interpretacje. Warszawa: PWN.

Walkowski, M. (2013). Przyczyny powstania globalnego kryzysu finansowego 2008+: analiza i porównanie wybranych opinii. Przegląd Strategiczny, 2. doi:10.14746/ps.2013.2.11.
Informacje uzupetniające

Wkład autorski: autor zaakceptował ostateczną wersję artykułu.

Źródła finansowania: artykuł został w całości sfinansowany ze środków własnych autora.

Uwagi: wyniki badania byly zaprezentowane w innej formie, tj. pracy licencjackiej Kowalski (2018).

Chicago School's neoliberalism and the economic crisis of the 21st century in the United States

\begin{abstract}
Motivation: The crash in the US financial market in 2008 resulted in a crisis of a global nature. A serious debate on its causes has begun, and in it there are voices about the important role of neoliberal assumptions in the Chicago trend, perceived as an economic concept and ideology affecting the broadly understood political and social sphere. The willingness to present such a critical evaluation was the direct cause of this topic.

Aim: The aim of the article is to identify the potential impact of the Chicago School's neoliberalism and the state's economic policy based on this doctrine on the 2008+ economic crisis in the United States.

Materials and methods: A method of critical analysis of literature in the field of economic crises theory, neoliberalism, neoliberalism of the Chicago school and the 21st century crisis was used.

Results: Due to the differences, it is difficult to clearly indicate whether and to what extent the Chicagós neoliberalism and the economic policy based on this doctrine contributed to the 2008+economic crisis. Due to the clearly prevailing voices of opponents of this doctrine and their reflections, it can be concluded that such an influence exists.

Keywords: crisis; United States; neoliberalism of the Chicago trend JEL: G2; N2; E5
\end{abstract}


